\title{
ETNISITAS, POLITIK, DAN \\ PEMBANGUNAN NEGARA BANGSA \\ DI MALAYSIA
}

\section{Oleh: Mohammad Maiwan*}

\begin{abstract}
Malaysia is a multiethnic country, in which ethnic factors as the basis of political interests. So far, efforts to create national integration have been directed at strengthening relations between ethnic groups and creating a political balance for all peoples. Efforts to build a nation state are conducted through policy: political cooperation, economic affirmation for ethnic Malays, education, and strengthening the position of Malay as the national language. The challenge to the nation-state development in Malaysia emerged during the economic crisis of 1998. The conflict brought political divisions among Malaysians, especially Malays. After Mahathir Mohamad's reign, efforts to promote national unity were carried out by introducing a moderate and tolerant concept of Islam Hadhari. During the leadership of Najib Razak, efforts to build a nation state were undertaken under the idea of One Malaysia. One of the challenges of developing a nation today is: The widening of gaps, racial prejudices, increased group identity, intolerance and corruption.
\end{abstract}

Key Words: Ethnicity, Politics, Nation Building, Malaysia.

Pendahuluan

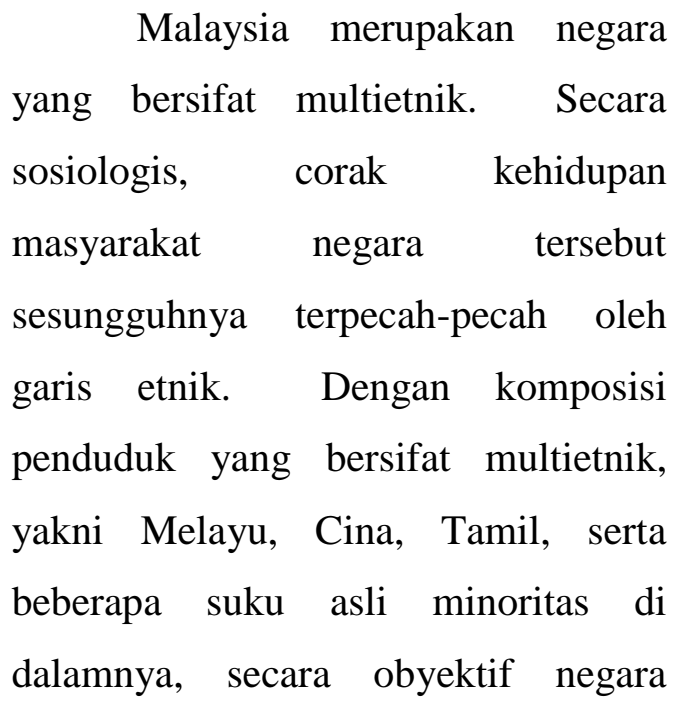

tersebut menghadapi tantangan cukup serius untuk mengembangkan diri sebagai suatu negara nasional yang kuat dan stabil. Dalam prakteknya, spektrum politik terfragmentasi mengikuti garis-garis etnik, di mana unsur etnis menjadi basis serta titik tolak kepentingan politik. Isu-isu politik yang muncul dalam politik lokal maupun nasional serta garis kebijakan yag ditempuh pemerintah hampir tidak

*Dosen pada Program Studi PPKn, Fakultas Ilmu Sosial Universitas Negeri Jakarta 
dapat dipisahkan sepenuhnya dari pertimbangan kepentingan etnik.

Kemajemukan yang demikian, menyebabkan pemerintah yang berkuasa dituntut secara bijak mampu mengelola konflik yang berkembang agar tidak menjadi gangguan terhadap stabilitas nasional. Dalam batas-batas tertentu, pemerintah berusaha keras mengakomodasi kepentingankepentingan yang lebih luas dengan menyeimbangkan antara tuntutantuntutan partikularistik yang bersifat perkauman di satu pihak, dengan kepentingan nasional di lain pihak. Beberapa insiden dalam sejarah politik Malaysia menunjukkan betapa seriusnya ancaman terhadap integrasi nasional mereka, yang berhujung kepada lahirnya berbagai kebijakan penting yang menjadi landasan bagi pembangunan negara bangsa.

Selama ini, sepanjang pemerintahan Barisan Nasional berkuasa, terutama dalam era kepemimpinan panjang mantan Perdana Menteri Mahathir Mohamad selama kurang lebih 22 tahun, negara tersebut mampu berkembang secara dinamis, bahkan menjadi salah satu negara yang berhasil menaikkan taraf kehidupan rakyatnya pada tingkatan negara menengah secara ekonomi. Akan tetapi, seiring dengan perjalanan waktu, dan berlakunya transformasi di segala bidang, yang begitu pesat dan menyeluruh dewasa ini, serta pengaruh eksternal yang tidak bisa dihindari, telah melahirkan tantangan baru yang menyebabkan pemerintah mesti bekerja lebih keras mengejar cita-citanya untuk mewujudkan suatu "Bangsa Malaysia". Meskipun sudah lebih dari lima puluh tahun konsep kerjasama politik antar etnik dipraktekkan, dan pertumbuhan kelas menengah cukup tinggi, namun identifikasi etnik masih wujud sebagai identitas sosial di kalangan masyarakat umum Malaysia. Keadaan semacam ini menyebabkan keraguan sosiopolitik terhadap kemampuan Malaysia untuk membentuk suatu identitas bangsa atau nasionalisme yang melampaui batasanbatasan etnik.

Jika dibandingkan dengan sejumlah negara-negara Asia Tenggara yang lain, proses Malaysia untuk membangun suatu negara bangsa yang 
harmonis danstabil, sesungguhnya cukup unik dan kompleks. Hal ini berakar dari sejarah, struktur masyarakat, serta corak sosio-kultural masyarakatnya yang khas. Dari segi ini, usaha pembangunan negara bangsa yang dilakukan sesungguhnya masih jauh dari harapan. Berdasarkan kenyataan tersebut, artikel ini berusaha memaparkan tentang apa saja langkahlangkah dan pengalaman yang ditempuh pemerintah Malaysia untuk mewujudkan suatu negara bangsa yang bersatu selama ini? Faktor-faktor apayang mempengaruhinya dan bagaimana implikasinya terhadap kehidupan nasional mereka?

\section{Etnisitas Dalam Politik Malaysia}

Munculnya dimensi etnik dalam perpolitikan di Malaysia bukanlah merupakan faktor yang baru. Hal tersebut telah berkembang jauh sebelum negara Malaysia moderen lahir. Bermula dari kebijakan pemerintah kolonial Inggris pada abad ke 19 yang membawa masuk orangorang Cina daratan untuk dipekerjakan sebagai buruh tambang di
Semenanjung Tanah Melayu. Selain itu dibawa masuk pula tenaga buruh dari orang-orang Tamil di Sri Lanka yang bekerja di sektor perkebunan karet dan juga tanaman sawit. Kebutuhan akan tenaga kerja kasar yang begitu besar menyebabkan pemerintah kolonial secara bergelombang membawa ribuan buruh memasuki negara tersebut. Selain itu, terdapat pula imigran dari gugusan kepulauan di Nusantara, yang berlangsung secara alamiah, yang merupakan bagian dari sub rumpun Melayu Nusantara. Mereka seperti, orang Jawa, Minangkabau, Bugis, Banjar, Palembang, Jambi, Aceh, dan lain-lain. Kesamaan-kesamaan agama, tradisi, bahasa dan adat istiadat menyebabkan rumpun-rumpun etnik tersebut lebih mudah berasimilasi dengan masyarakat setempat (Azmah Abdul Manaf 2001).

Sementara kelompok migran orang-orang Cina dan Tamil yang memiliki perbedaan-perbedaan dari segi etnik, agama, bahasa, adat istiadat, dan budaya telah menimbulkan persoalan-persoalan baru. Menjelang Malaysia merdeka tahun 1957 jumlah 
golongan imigran, khususnya kaumCinanyaris menyamai masyarakat pribumi. Orang Melayu baru sadar bahwa mereka menjadi minoritas di negaranya sendiri. Dalam bidang politik masyarakat keturunan imigrantersebut mulai berani menyuarakan tuntutan persamaan politik, khususnya hak mendapatkan kewarganegaraan dalam negara Malaysia merdeka. Keadaan inilah yang membangkitkan kesadaran orang Melayu untuk melindungi kepentingankepentingan politik, ekonomi, dan sosial serta budaya mereka agar tidak terpinggirkan. Sejak saat itu, isu-isu nasional tidak bisa dipisahkan dari kepentingan etnik yang saling bersaing dalam panggung kehidupan nasional. Dengan kata lain, dimensi etnik secara inheren telah menjadi bagian dari kerangka dan formasi politik Malaysia sejak awal.

Kajian-kajian para pakar menunjukkan bagaimana sentimen etnik tersebut memberikan pengaruh mendasar terhadap wujudnya gagasan konstitusi politik yang berlandaskan konsosiasionalisme sebagai bentuk akomodasi. Sebagaimana dikemukakan oleh Milne dan Mauzy (1978) politik etnik memiliki akar yang dalam, yang menjadi isu krusial bagi lahirnya satu model konstruksi pemerintahan konsosiasional Malaysia yang berusaha menjembatani kepentingan semua golongan. Meskipun awal kebangkitan nasionalisme Malaysia dipelopori golongan Melayu (Roff 1994), namun pada kenyataannya mereka tidak bisa menafikan kewujudan kelompokkelompok non Melayu yang sudah bertapak kukuh di negara tersebut. Hal ini membawa implikasi pada lahirnya suatu konsensus politik yang mengakomodasi konsep negara bangsa majemuk. Aspek ini berkelindan dengan aspek agama sehingga mempengaruhi lahirnya kebijakankebijakan pemerintahan Malaysia yang berdimensi etnik (Mutalib 1990). Abdul Rahman Embong (2000) dalam kajiannyamenggariskan wujudnya politik etnik memberikan warning bagi setiap pemerintahan yang berkuasa di Malaysia untuk selalu sadar dan bersikap hati-hati dalam mengambil 
setiap kebijakan. Menurut beliau, integrasi nasional Malaysia bertumpu pada sejauh mana masyarakat mampu mentransformasikan loyalitas primordialnya melampaui batasanbatasan sempit perkauman menuju negara bangsa yang kuat. Walaupun selama ini wujud kerjasama politik di antara etnik di Malaysia, namun hal tersebut lebih bersifat elitis dan fisikal tanpa melibatkan pembentukan nilai, norma, dan juga kesadaran yang bersifat non etnik. Apa yang nampak dalam kehidupan sehari-hari lebih bersifat kosmetik, di mana nasionalisme yang muncul bercirikelompok, yang lebih menonjolkan etnik masing-masing.

\section{Proses Pembangunan Negara Bangsa}

Salah satu titik penting dalam sejarah Malaysia yang menjadi pencetus lahirnya kebijakan yang bersifat socio and political engineering adalah insiden kerusuhan rasial bulan Mei 1969. Insiden itu membuka mata banyak kalangan akan pentingnya mengelola perbedaan-perbedaan dalam masyarakat, sehingga tidak menimbulkan benturan keras. Secara khusus konflik rasial itu melahirkan kesadaran di kalangan pemerintahan dan rakyat Malaysia bahwa integrasi nasional mereka sangat rapuh. Karena itu perlu diwujudkan suatu platform politik baru yang mampu menjadi dasar pengikat semua kaum dalam kehidupan negara. Pada level institusional pemerintah kemudian mendirikan lembaga Majelis Gerakan Negara (Mageran) yang dipimpin oleh Timbalan Perdana Menteri ketika itu, yakni, Tun Abdul Razak Hussein. Majelis ini memiliki kewenangan dalam melakukan rekonstruksi nasional di masa darurat pasca kerusuhan. Melalui Mageran kemudian didirikan Majelis Perpaduan Negara (MPN)untuk menangani isu-isu pembinaan integrasi masyarakat.

Selain itu, MPN dirancang untuk menjadi think thank pemerintah dalam merumuskan kebijakankebijakan untuk mewujudkan kehidupan masyarakat harmonis. Secara khusus Lembaga Perpaduan Negara memiliki tugas strategis dalam 
menyusun program-program yang mampu mengarahkan seluruh lapisan masyarakat menjadi bagian dari bangsa Malaysia secara keseluruhan. Meskipun demikian, tidak jarang lembaga ini juga menjadi alat propaganda pemerintah untuk mempromosikan kebijakan-kebijakan rejim dalam konteks politik nasional. Pada tahun 2004 lembaga tersebut berubah menjadi Lembaga Perpaduan Negara dan Integrasi Nasional. Sementara pada level ideologis pemerintah kemudian merumuskan satu doktrin Rukun Negara yang menjadi prinsip dasar kehidupan kebangsaan mereka. Doktrin tersebut merupakan filsafat nasional bangsa yang bertujuan untuk menciptakan persatuan dan keserasian di antara etnik-etnik yang berbeda. Rukun Negara berisi lima prinsip yakni: Kepercayaan Kepada Tuhan; Kesetiaan kepada Raja dan Negara; Keluhuran Perlembagaan; Kedaulatan UndangUndang; Kesopanan dan Kesusilaan. Prinsip ini mirip dengan Pancasilanya Indonesia.
Kedua aspek di atas kemudian diikuti dengan penciptaan kebijakan Dasar Ekonomi Baru, yang berisi serangkaian program-proram pembangunan ekonomi negara yang memberikan keutamaan kepada golongan pribumi (Melayu) yang secara ekonomi jauh tertinggal dibandingkan dengan golongan Cina. Dalam kebijakan tersebut pemerintah mensasarkan dan memastikan bahwa equity kue nasional akan dibagi secara proporsional untuk menghindari ketimpangan yang terlalu jauh. Kebijakan ini memberikan alasan secara politis maupun ekonomi kepada pemerintah untuk mendiskriminasi kelompok di luar etnik Melayu. Pemerintah menganggap bahwa dominasi ekonomi golongan Cina yang terlalu besar dapat menjadi hambatan besar bagi persatuan nasional. Karena itu, melalui suatu langkah "afirmasi positif" diharapkan kalangan pribumi mampu mengejar ketertinggalan mereka dalam pembangunan.

Pada tingkat tertentu, Konsep Dasar Ekonomi Baru secara bertahap berhasil mewujudkan satu lapisan kelas 
menengah Melayu yang tumbuh secara pesat. Mereka berhasil memperoleh kesuksesan ekonomi melalui kontrakkontrak yang diberikan pemerintah, ataupun membuka bidang usaha baru yang difasilitasi pemerintah dengan mudah. Lahirnya program-program ekonomi yang bersifat afirmatif ini secara pesat juga dibarengi dengan perluasan akses pendidikan khususnya pendidikan tinggi terhadap golongan pribumi, sehingga lahirlah golongan professional baru dalam bidang-bidang moderen yang begitu banyak yang tidak terbayangkan sebelumnya. Mereka mengisi pekerjaan-pekerjaan di berbagai perusahaan milik negara serta swasta yang berkembang secara dinamik.

Penerapan Dasar Ekonomi Baru tersebut berkembang dengan pesat dan kelihatan hasilnya semenjak tahun 1980-an di bawah Perdana Menteri Mahathir Mohamad, ketika Malaysia melancarkan industrialisasi secara besar-besaran. Transformasi ekonomi negara berubah dengan drastik dan golongan pribumi memperoleh manfaat besar. Namun demikian, pada sisi lain, patronase ekonomi yang diberikan pemerintah menjadikan golongan pribumi terlalu tergantung pada pemerintah dan ujung-ujungnya menumbuhkan etos ekonomi yang lemah. Harapan bagi lahirnya etos kewiraswastaan yang kuat dijungkirkan oleh kenyataan banyaknya praktekpraktek penyalahgunaan yang dilakukan. Banyak di antara golongan pribumi yang malas berusaha, dan lebih menggantungkan subsidi dan proteksi, serta menjual lisensi-lisensi yang diperoleh kepada golongan Cina (Jamaie Hj. Hamil 2004: 43-44).

Praktek dagang Ali-Baba ini bukanlah rahasia umum, dan bahkan pada taraf tertentu dipelihara oleh sebagian besar para pimpinan politik dalam pemerintahan Barisan Nasional. Alih-alih pembangunan ekonomi yang seharusnya menjadi instrumen dalam memperkuat integrasi nasional tidak sepenuhnya terwujud. Sampai dengan pertengahan tahun 1990-an ketika kebijakan Dasar Ekonomi Baru diakhiri, pembagian ekonomi nasional belumlah sepenuhnya dapat dikatakan adil. Dominasi ekonomi golongan Cina 
tetaplah besar, sementara kekayaan ekonomi masyarakat Melayu di luar korporasi-korporasi negara masih di bawah 30\%. Bahkan Mahathir Mohamad sendiri kecewa dengan perilaku sebagian golongan menengah Melayu yang telah dibesarkan dengan kebijakan tersebut, yang telah menjadi kaya, namun justru lupa dengan asal usulnya dan menjadi pendukung nilainilai konservatisme, yang membiarkan golongan pribumi Melayu lain di lapis bawah yang masih tertinggal. Mereka ini sering disebut sebagai Melayu Baru. Jamaie Haji Hamil (2004) dalam kajiannya menegaskan bahwa campur aduk antara kepentingan politik dan bisnis inilah yang menjadikan program afirmasi tersebut tidak berhasil secara memuaskan. Para tokoh politik berlomba memburu rente untuk meneguhkan jalinan patronase mereka sekaligus membiakkan nilai-nilai kemapanan.

Namun demikian, bagaimanapun juga munculnya Malaysia sebagai negara semi industrial dengan kekuatan yang cukup maju, telah ikut membentuk lanskap bagi tumbuhnya keyakinan baru akan identitas Malaysia sebagai bangsa yang sedang membangun. Secara praktis, interaksi ekonomi-politik yang terjalin antara berbagai kelompok etnik di Malaysia dalam kerangka DEB di atas, dengan kapitalisme sebagai nilai dasarnya, telah membentuk suatu kelompok masyarakat Malaysia yang melampaui batasan etnik (Means 1990). Selain ditumpukan pada bidang ekonomi, dimensi pembangunan negara bangsa diletakkan pada bidang pendidikan serta penggunaan Bahasa Melayu sebagai bahasa resmi di lembaga-lembaga pemerintah. Semenjak tahun 1970-an setelah adanya perluasan kesempatan pendidikan, pemerintah mendorong berdirinya sekolah-sekolah kebangsaan (nasional) mulai dari sekolah tingkat dasar sampai dengan menengah. Kurikulum pendidikan didesain sedemikian rupa dengan memperkenalkan subjek-subjek wajib seperti: Sejarah Malaysia, Bahasa Malaysia, Pendidikan Moral, serta Kenegaraan Malaysia. Materi-materi tersebut diharapkan dapat memperkuat 
nilai-nilai murni masyarakat serta menanamkan keyakinan peserta didik sebagai warganegara yang patriotik. Selain itu, institusi pendidikan dapat menjadi sarana efektif di dalam menyuntikkan dan menanamkan kesadaran terhadap individu tentang pentingnya nilai-nilai dan sistem politik yang diterapkan.

Meskipun pada kenyataannya sekolah-sekolah kebangsaan lebih banyak di isi oleh kaum Melayu, dan kurang dapat menarik golongan Cina maupun Tamil, namun pemerintah tetap menghargai adanya sekolahsekolah beraliran Cina maupun Tamilsebagai wujud pengakuan terhadap kemajemukan masyarakat. Pada tahap tertentu, kekhawatirankekhawatiran akan munculnya perpecahan yang bersumber dari dunia pendidikan selalu ada. Namun pemerintah tetap berusaha untuk mencegahnya. Salah satu langkah penting yang dilakukan oleh pemerintah dalam hal ini adalah memperkenalkan konsep Sekolah Wawasan. Sekolah Wawasan adalah sekolah yang dirancang untuk menampung semua kelompok dalam satu wadah pendidikan tanpa melihat latarbelakang agama, etnik, bahasa, dan suku. Tumpuan utama Sekolah Wawasan adalah tersemainya nilainilai karakter individu-individu peserta didik yang unggul, bersatu dan patriotik. Pada tahun 1990-an gagasan pendirian sekolah tersebut sejalan dengan visi Wawasan 2020 dari Mahathir Mohamad untuk mempersiapkan Malaysia sebagai negara maju.

Sementara penggunaan Bahasa Malaysia sebagai bahasa resmi negara diperkenalkan mengingat bahasa ini merupakan salah akar pembentuk negara Malaysia serta digunakan secara dominan oleh etnik pribumi. Dalam tahun-tahun 1990-an dan 2000-an terjadi perdebatan meluas menyusul keputusan Mahathir untuk menggunakan Bahasa Inggris dalam pengajaran subyek-subyek sains di sekolah. Sebagian kalangan yang khawatir dengan tergerusnya posisi Bahasa Melayu menyerang kebijakan tersebut sebagai berbahaya dan salah kaprah. Menurut mereka, penguasaan 
sains oleh sebuah bangsa tidaklah semata-mata ditentukan oleh bahasa yang digunakan, tetapi yang lebih penting adalah memahami subyek materi yang diajarkan. Kalangan ini berargumen bahwa, bangsa-bangsa penutur non Bahasa Inggris juga bisa maju menyamai bangsa-bangsa penutur Bahasa Inggris, seperti: Perancis, Jerman, Spanyol, Jepang, Korea Selatan, Taiwan, Cina.

\section{Pembangunan Negara Bangsa dan Tantangannya}

\section{Gugatan}

terhadap

pembangunan negara bangsa di Malaysia mengalami ujian ketika tahun 1998 negara tersebut dilanda krisis ekonomi yang berujung pada konflik politik antara Mahathir dan deputinya yakni Anwar Ibrahim yang dicopot dari jabatannya. Usaha-usaha Anwar Ibrahim dan golongan oposisi untuk melakukan perlawanan terhadap pemerintahan Mahathir membawa situasi ketidakpastian politik dan perpecahan di kalangan bangsa Malaysia, khususnya kaum Melayu. Golongan oposisi memandang
Mahathir bertindak sewenang-wenang dan memfitnah Anwar. Dalam waktu yang singkat spektrum politik berubah drastik. Partai UMNO yang merupakan tulang punggung Barisan Nasional mengalami perpecahan hebat, di mana sebagian tokoh-tokohnya membelot ke kubu Anwar. Penangkapan dan pemenjaraan terhadapnya semakin mempertebal keyakinan golongan oposisi bahwa Mahathir sengaja merancang usaha sistematis untuk menamatkan karier politik Anwar sekaligus mengenyahkan seluruh lawan-lawan politiknya.

Usaha-usaha perlawanan secara politik dilakukan melalui partai oposisi yakni Partai PKR (Partai Keadilan Rakyat) yang didirikan Anwar Ibrahim sejurus sebelum beliau dipenjara. Dalam pemilihan umum yang dilakukan bulan November tahun 1999Barisan Nasional mengalami kemerosotan suara, di mana kelompok tersebut memperoleh 148 kursi dalam parlemen. Padahal dalam pemilihan umum tahun 1995 mampu merebut 162 kursi parlemen. Sementara partaipartai oposisi yang tergabung dalam 
Barisan Altrnatif memperoleh 42 kursi, yang berarti mengalami lonjakan kenaikan.

$$
\text { Pergeseran suara ini }
$$

menunjukkan adanya sokongan kuat terhadap bangkitnya kelompok oposisi sekaligus simpati terhadap Anwar Ibrahim. Suara golongan Melayu yang secara tradisional biasanya diberikan kepada UMNO ataupun partai berhaluan Islam yakni Partai Islam seMalaysia (PAS) pada saat itu terpecah, sebagian beralih kepada PKR. Perolehan suara oposisi yang naik tersebut merupakan sinyal kuat ketidaksukaan rakyat terhadap sikap represif rejim sekaligus bukti bahwa orang Melayu tidaklah selalu satu suara. Namun yang lebih penting lagi, di kalangan golongan muda politisi Melayu, bisa bekerjasama dan beraliansi dengan politisi etnik non Melayu. Pemihakan golongan Melayu terhadap partai-partai oposisi tersebut memicu kemarahan pemerintah sehingga menyerang beberapa media massa cetak berbahasa Melayu yang kritis dan bebas, seperti: Eksklusif, dan Detik, yang langsung ditutup, serta
Harakah yang dibatasi terbitnya dari dua kali seminggu menjadi dua kali dalam sebulan.

Kehadiran PKR dalam pentas politik nasional Malaysia untuk selanjutnya memberikan warna tersendiri bagi kelangsungan kelompok oposisi serta ujian baru untuk mewujudkan sistem kepartaian yang bersifat terbuka dan multietnik. PKR sendiri merupakan partai multietnik yang merangkumi semua golongan dan berlandaskan platform ideologi yang sekuler. Akan tetapi konsolidasi kekuasaan yang dilakukan oleh Mahathir dalam UMNO dan juga Barisan Nasional terus dilakukan seiring dengan keberhasilannya mengatasi krisis dan melewatinya dengan selamat. Hegemoni UMNO dalam kekuasaan menjadi penanda kuatnya infrastruktur dan pengaruh partai ini dalam politik Malysia. John Hilley (2001) menjelaskan bahwa stabilitas hegemonik yang diciptakan UMNO yang begitu panjang tidak terlepas dari kecerdikan figur Mahathir yang dengan segala cara menciptakan blok legitimasi dalam segenap aspek 
dalam negara. Perpaduan antara koersi dengan manipulasi yang dibarengi dengan keberhasilan dalam pengelolaan ekonomi negara.

\section{Pembangunan Negara Bangsa Dalam Politik Pasca Mahathir}

Seiring mundurnya Mahathir dari kekuasaan tahun 2003, politik Malaysia mengalami transformasi baru. Meskipun politik negara secara fundamental tidak berubah, tetapi mengalami beberapa pergeseran. Di bawah Perdana Menteri Abdullah Ahmad Badawi usaha-usaha untuk memupuk persatuan nasional khususnya di kalangan golongan Melayu, serta hubungan di antara kaum tetaplah dilakukan secara intensif. Badawi yang merupakan figur moderat dan bukan kontroversial sangat menaruh perhatian pada dimensi masyarakat pedesaan dan juga kelas bawah. Ia menekankan pentingnya menjaga pertumbuhan dan pemerataan ekonomi yang stabil dan berjangka panjang, seraya meningkatkan kualitas pendidikan di seluruh negara sebagai kunci pembangunan bangsa (Chamil Wariya 2004).

Sebagai salah satu negara yang berhasil secara ekonomi dan meletakkan nilai-nilai toleransi dalam prioritas kehidupan, Badawi ingin menjadikan Malaysia sebagai contoh bagi negara-negara lain dalam pembangunan, khususnya negaranegara Muslim. Dalam konteks pembangunan negara bangsa, beliau memperkenalkan konsep Islam Hadhari atau Islam moderat yang bertumpu pada pengetahuan dan kemajuan peradaban Islam. Konsep Islam Hadhari berintikan sepuluh prinsip utama yang pada intinya adalah penerapan nilai-nilai Islam yang toleran dan menghargai perbedaan dengan kelompok lain berdasarkan semangat saling menghormati. Rujukan doktrin ini adalah kemajuan Islam di masa lampau yang menghargai adanya perbedaan dan hidup berdampingan dengan kelompok lain. Peradaban Islam pada puncak-puncak kejayaannya, baik pada masa dinasti Abbasiyah di Bagdad maupun Umayyah II di Andalusia pada abad 
pertengahan digambarkan sebagai puncak-puncak kemajuan dan kemenangan rasionalitas yang sejajar dengan nilai-nilai keimanan sepertimana ditekankan dalam Islam (Abdullah Ahmad Badawi 2007).

Usaha untuk mengenalkan doktrin Islam Hadhari ditempuh sebagai jalan pemecahan untuk mengintegrasikan kepentingankepentingan yang berseberangan, yakni antara golongan Islam dalam pemerintahan di satu sisi serta kelompok-kelompok Islam konservatif yang tergabung dalam partai-partai oposisi Islam yang terus menerus menyudutkan pemerintahan sekuler Barisan Nasional. Selain itu konsep tersebut diyakini untuk meredam kekhawatiran golongan bukan Muslim terhadap kebijakan-kebijakan pemerintah yang dianggap diskriminatif. Doktrin Islam Hadhari dipandang sebagai jalan tengah, di mana negara meskipun bersifat Islam tetapi mengakui kebebasan kelompokkelompok lain yang adayang tetap harus dilindungi.
Namun demikian, doktrin ini diserang oleh kelompok oposisi islamis di negara itu sebagai jungkir balik dan penuh kerancuan. Juru bicara utama golongan oposisi yakni, Abdul Hadi Awang, yang juga Presiden PAS ketika itu menyebut konsepsi Islam Hadhari sebagai salah kaprah dan menyesatkan. Lebih bersifat politis ketimbang substantif dalam memajukan kepentingan Islam. Hal tersebut bertentangan dengan tindakan-tindakan pemerintah sendiri terhadap golongan Islam, di mana pemerintah tidak pernah ragu untuk menumpas aspirasi-aspirasi politik golongan Muslim. Menurut beliau, Islam adalah satu, tidak mengenal embel-embel, sementara Islam Hadhari merupakan varian lain yang secara implisit menyangkal otentisitas Islam itu sendiri (2005).

Dalam pandangan Hadi Awang, justru yang perlu dikembangkan oleh Malaysia adalah mendorong terwujudnya nilai-nilai Islamis dalam praktek kehidupan masyarakat di segala bidang di tengah serbuan nilai sekuler Barat. Islam dan masyarakat Melayu merupakan dua entitas yang 
tidak dapat dipisahkan, yang membentuk jati diri negara Malaysia modern. Pijakan yang tepat untuk hal ini adalah ajaran Islam yang murni yang memberikan inspirasi bagi kemajuan peradaban pada masa lalu. Dalam pandangan beliau, yang perlu dikembangkan adalah Hadharoh Islamiyah, yakni suatu peradaban Islam yang unggul, dan bukan Islam Hadhari. Sementara pada masa kepemimpinan Najib Razak, sejak tahun 2009 sampai sekarang ini usahausaha untuk mewujudkan masyarakat Malaysia yang padu dilakukan secara lebih progresif lagi. Langkah-langkah membina kehidupan kebangsaan dilakukan di tengah pesatnya pembangunan yang diwarnai kritisisme rakyat, merebaknya praktek-praktek korupsi, serta usaha-usaha UMNO untuk meneguhkan kembali cengkeramannya terhadap kekuasaan. Dalam banyak aspek pemerintah memperoleh manfaat yang besar melalui insitusi-institusi pendidikan maupun media yang memiliki fungsi strategis dalam menyebarkan dan menanamkan ide-ide kebangsaan.
Melalui institusi pendidikan, yang maju pesat dalam beberapa dekade ini pemerintah berhasil menstimulasi dan mengarahkan agar rakyat menjadi lebih loyal dan patriotik.

Salah satu gagasan penting yang sering digembar gemborkan Perdana Menteri Najib Tun Razak untuk mewujudkan kesadaran kebangsaan adalah konsepsinya tentang One Malaysia, yakni suatu slogan yang secara substantif berisi pernyataan bahwa semua kaum di Malaysia meskipun berbeda-beda etnik, golongan, kelas, agama, dan budaya, tetapi hakikatnya adalah satu. Mereka semua adalah bangsa Malaysia (Suhana Saad 2012: 24-39). Konsepsi ini dikeluarkan pemerintah sebagai respon terhadap meningkatnya kekhawatirankekhawatiran akan perpecahan dalam masyarakat menyusul adanya kritikkritik dan ketidakpuasan terhadap pemerintah. Pembangunan ekonomi yang pesat di Malaysia, dalam banyak hal telah melahirkan ketimpanganketimpangan baru, yang secara automatik mencetuskan ketegangan antar etnik. Tidak semua golongan 
memperoleh manfaat langsung dari pembangunan. Golongan-golongan tertentu, seperti orang-orang Tamil dan juga penduduk Melayu di pedesaan, serta kelas menengah ke bawah di perkotaan tetaplah kesulitan menaikkan taraf ekonominya. Sebagian besar golongan Melayu tetaplah terbelakang secara ekonomi dan bergantung sepenuhnya pada pemerintah. Juga minoritas etnik Tamil yang tetap merasa sebagai warganegara kelas dua. Sementara golongan Cina yang merupakan minoritas besar dalam masyarakat pribumi Melayu semakin melaju pesat dalam menguasai sumbersumber ekonomi negara.

Kemajuan-kemajuan teknologi dan informasi, serta liberalisasi ekonomi yang dilancarkan pemerintah, dalam banyak aspek justru membuka ruang yang lebih luas bagi golongan Cina untuk berusaha. Namun pada segi lain, aspirasi-aspirasi politik mereka tetap dibatasi. Kenyataan ini bertentangan dengan fakta bahwa seharusnya kemajuan-kemajuan ekonomi diimbangi dengan langkah keterbukaan yang lebih besar serta kesetaraan politik. Meskipun pemerintahan Najib Razak sendiri melakukan beberapa kemajuan dalam aspek politik, terutama kebebasan dalam menyuarakan aspirasi, tetapi masih belum cukup memadai untuk mendorong terwujudnya suatu kontrol kekuasaan yang efektif (Lee 2017).

Dewasa ini golongan nonMelayu yang terdidik semakin sadar akan hak-hak politiknya, sehingga semakin berani melakukan agresi terhadap kebijakan-kebijakan pemerintah yang dirasa diskriminatif. Akomodasi politik, dalam arti toleransi ataupun kerjasama politik antar kaum dalam koalisi Barisan Nasional dipandang lebih mencerminkan kepentingan elite yang mengatasnamakan kaum masingmasing. Semenjak tahun 1990-an golongan Cina dan juga India secara terus menerus mendesakkan tuntutan yang lebih besar akan hak-hak mereka dalam politik nasional maupun pembagian kue ekonomi ataupun pengekalan identitas mereka. Kaum India misalnya, pada bulan Juli 2009 mendirikan organisasi Hindraf (Hindu 
Rights Action Force) atau Barisan Bertindak Hak Hindu, yang merupakan gabungan 30 NGO India yang bertujuan mengekalkan hak dan warisan masyarakat Hindu dalam masyarakat multirasial Malaysia yang sekuler.

Mereka mengumandangkan slogan People's Power (Makkal Sakthi) dalam menuntut persamaan hak kepada pemerintah. Munculnya kelompokkelompok seperti ini memberikan impak cukup besar dalam lanskap politik Malaysia, sehingga menyadarkan golongan minoritas lain ataupun kelompok-kelompok kepentingan tertentu bangkit menggugat hak-haknya. Sikap agresif Hindraf memperoleh perhatian serius pemerintah, di mana sebagian kalangan bahkan menyebutnya sebagai ekstremis yang mengancam keserasian hubungan antar etnik. Pada bulan April 2017 suatu koalisi yang terdiri dari $22 \mathrm{NGO}$ Muslim Melayu yang tergabung dalam Barisan Bertindak Melayu Islam (Bertindak) mendesak pemerintah untuk membubarkan Hindraf (www. freemalaysiatoday. com diunduh pada tanggal 16 Juni 2017 pukul 10. 46).

Pada tataran lain, golongan muda Melayu yang berpendidikan tinggi dan terbuka dengan teknologi informasi terkini cenderung memiliki haluan politik yang lebih liberal dan kritis, berani mengambil posisi politik yang berbeda dengan arus utama. Pada bulan November 2007 berbagai etnik yang tergabung dalam organisasi Bersih melakukan demonstrasi menuntut adanya pemilihan umum yang jujur. Insiden itu mencetuskan nama-nama tokoh oposisi utama dalam satu barisan penentangan seperti: Anwar Ibrahim, Abdul Hadi Awang, Lim Kit Siang, Lim Guan Eng, Kamaruddin Jaafar, Khalid Ibrahim. Fenomena ini tentu saja dapat menjadi ancaman terhadap kedudukan Barisan Nasional. Munculnya partai-partai politik dengan platform yang bersifat mutltietnik dan juga asosiasi-asosiasi masyarakat sipil dari beragam golongan menjadi indikator kuat akan adanya tuntutan yang lebih besar untuk mewujudkan masyarakat Malaysia yang demokratis. 
$\begin{array}{rrr}\text { Pendemokrasian } & \text { melalui } \\ \text { institusi-institusi sipil ini } & \text { bahkan } \\ \text { semakin meningkat pasca } & \text { krisis }\end{array}$ ekonomi tahun 1998. Dalam dua puluh tahun terakhir partai-partai politik yang bersifat multietnik yang dimotori PKR menjadi kekuatan alternatif yang tidak bisa dipandang enteng. Insiden terakhir dalam pemilu 2009 dan 2014 menunjukkan bagaimana masyarakat Malaysia dikejutkan oleh besarnya dukungan terhadap partai oposisi. Kelompok-kelompok oposisi yang tergabung dalam Koalisi Rakyat berhasil menjungkirkan reputasi Barisan Nasional sebagai kekuatan mayoritas mutlak dalam parlemen. Dalam pemilihan umum tahun 2013 misalnya, Barisan Nasional berhasil meraih 133 kursi parlemen, sementara Koalisi Rakyat mengalami lonjakan dengan meraih 89 kursi. Pesan yang disampaikan para pemilih secara jelas menunjukkan keinginan kuat untuk berubah. Para pemilih muda di kalangan masyarakat sebagian besar sudah muak dengan kepemimpinan para politisi tua Barisan Nasional, khususnya UMNO yang sejak dulu dianggap kurang menunjukkan kepemimpinan politik yang responsif. Alih-alih mendukung partai UMNO, mereka justru memilih partai-partai oposisi di luar Barisan Nasional. Sejumlah politisi kawakan yang selama ini menjadi tokoh penting dalam pemerintahan bahkan ditumbangkan oleh para pemimpin oposisi di daerah pemilihan mereka masing-masing. Kasus yang menimpa tokoh UMNO Sahrizat Abdul Jalil yang dikalahkan oleh Nurul Izzah Anwar yang merupakan politisi baru, di daerah pemilihan Lembah Pantai Kuala Lumpur, menjadi tamparan hebat bagi pihak Barisan Nasional. Begitu juga dengan beberapa tokoh lain.

Kalangan kritis di luar pemerintahan merasa cemas dengan beberapa kebijakan Najib yang mengarah pada otoriterisme baru. Sikap itu, seperti tindakan memenjarakan kembali Anwar Ibrahim tahun 2015 dengan tuduhan-tuduhan yang oleh banyak orang dianggap meragukan. Di samping itu, pemerintah tetap mengekang kekuatankekuatan oposisi melalui berbagai 
taktik dan caradalam setiap pemilihan lokal, maupun nasional dengan caracara yang tidak elegan. Sejumlah kasus yang mengiringi pemerintahan Najib menjadi isu penting yang menjadi amunisi bagi lawan-lawan politiknya, seperti kasus pembelian kapal selam dari Perancis yang bermasalah, pembunuhanmodel Altantuya Shaaribuu, sampai dengan gaya hidup glamour istri beliau, serta kepemilikan asset sejumlah tokoh-tokoh UMNO di luar negeri dan perusahaan-perusahan besar yang dimiliki kroni-kroni mereka. Hal tersebut menyebabkan kepercayaan rakyat pada pemerintah merosot.

Menjelang tahun baru 2014, yakni pada tanggal 31 Desember 2013 ribuan orang dari berbagai kalangan melakukan demonstrasi di Lapangan Merdeka Kuala Lumpur. Mereka memprotes kenaikan bahan bakar minyak dan kebutuhan hidup seharihari yang terus meningkat. Para demonstran membentangkan posterposter berisi tulisan: "Turunkan Harga", "Membela Hak-Hak Kami" dan juga berteriak, "Hidup Rakyat" (Kompas, 2 Januari 2014). Aksi itu dipicu oleh kebijakan pemerintahan yang mencabut subsidi bahan bakar minyak serta makin tingginya biaya hidup. Para pemrotes menganggap pemerintah mengambil kebijakan yang keliru dan membiarkan rakyat menanggung beban hidup yang berat. Kebangkitan kelompok oposisi ini sejajar dengan merosotnya pengaruh Barisan Nasional. Meskipun koalisi Barisan Nasional memenangi Pemilihan Umum pada Mei 2013 tetapi perolehan suara mereka merupakan yang terburuk sepanjang 50 tahun lebih Malaysia merdeka.

Sebelumnya pada akhir bulan April tahun 2012 tekanan terhadap pemerintah dilakukan oleh aliansi masyarakat sipil lintas golonganyang tergabung dalam kelompok Bersih. Demontrasi Bersih 3. 0. bertujuan menuntut reformasi sistem dan pelaksanaan pemilihan umum. Para pemrotes yang berjumlah lebih dari 60 . 000 orang memenuhi jalanan menuju Lapangan Merdeka di Kuala Lumpur. Mereka menuduh Komisi Pemilihan Umum berpihak dan mengklaim daftar pemilih telah dicurangi. Demonstrasi 
ini mencerminkan kekhawatiran terhadap pelaksanaan pemilihan umum yang bakal digelar, di mana koalisi Barisan Nasional telah berkuasa lebih dari lima puluh tahun. Demonstrasi itu berakhir dengan kerusuhan dan dibubarkan secara paksa oleh kepolisian (www. bbc. com/indonesia/dunia tanggal 28 April 2012).

Namun kasus terbesar yang meruntuhkan kepercayaan politik pada Najib Razak dan juga UMNO adalah terkuaknya skandal korupsi 1MDB (1 Malaysia Development Berhad), yakni skandal milyaran US dollar. Kasus ini bermula dari pendirian perusahaan investasi 1MDB oleh Najib Razak tahun 2009 yang bertujuan meningkatkan pertumbuhan ekonomi Malaysia. Namun kenyataannya perusahaan tersebut bangkrut setelah uang negara yang ditanam di BUMN itu lenyap tanpa penjelasan. Uang tersebut sebagian besar, yakni US\$ 700 jutajustru masuk ke kantong Perdana Menteri dan juga anggota keluarganya, serta beberapa kroninya. Najib menyangkal tuduhan itu, dengan menyatakan bahwa aliran dana dalam rekening pribadinya bukanlah uang BUMN tersebut melainkan donasi dari Raja Arab Saudi yang memang dikhususkan untuk dirinya.

\section{Pembangunan Negara Bangsa}

\section{Dalam Cakrawala Politik Baru}

Skandal 1MDB di atasmemicu reaksi keras masyarakat, mencetuskan demonstrasi massa besar, yang menganggap perdana menteri berbohong seraya menuntut mundur. Dalam beberapa waktu, bursa saham Malaysia dan nilai tukar mata uang ringgit terhadap dollar Amerika Serikat jatuh. Perekonomian negara dihadapkan pada tekanan pasar dan situasi politik yang tidak menentu, di mana terjadi perpecahan dalam pemerintahan. Sebagian kalangan yang tidak puas dalam pemerintahan berusaha menjadikan isu ini sebagai senjata politik untuk melawan PerdanaMenteri. Timbul kemelut politik dalam pemerintahan yang mendorong Najib Razak bertindak keras. Salah satu tokoh paling senior dalam pemerintahan, yakni, Timbalan 
Perdana Menteri Muhyiddin Yassin yang mempertanyakan kejujuran Najib didepak dari pemerintahan. Desas desus yang beredar, Muhyiddin berusaha memanfaatkan isu tersebut untuk kepentingan pribadinya, menggapai jabatan Perdana Menteri yang sudah lama diincarnya. Akan tetapi langkah yang lebih berani ditunjukkan oleh mantan Perdana Menteri Mahathir Mohamad yang menyerukan pada rakyat Malaysia untuk beramai-ramai memprotes dan menurunkan Perdana Menteri. Dalam berbagai kesempatan, Mahathir menyebut pemerintahan Najib berbahaya dan korup. Ia menyatakan kecewa dengan pemerintah yang tidak tanggap dengan suara-suara arus bawah. Bahkan Mahathir kemudian menyatakan keluar dari UMNO.

Menghadapi kenyataan ini suara oposisi sepakat bahwa kekuasaan Najib perlu diakhiri, tetapi sebagian di antara mereka menolak beraliansi dengan Mahathir mengingat praktekpraktek pemerintahan beliau yang otoriter di masa lalu. Kalangan oposisi Islamis misalnya, mengecam Mahathir sebagai pengecut, yang tidak kalah otoriternya pada masa lalu dibanding Najib. Dalam sejumlah kesempatan kalangan oposisi dan kekuatankekuatan kritis di luar pemerintahan beberapa kali melakukan demonstrasi besar dengan tujuan untuk menekan Najib mundur dari kekuasaan.

Pada bulan Agustus 2015 aksi demonstrasi yang dilakukan kelompok prodemokrasi, Bersih, mampu menarik ratusan ribu orang untuk menunut PM Najib mundur. Aksi damai yang berlangsung dua hari tersebut merupakan simbol solidaritas kelompok-kelompok di luar pemerintahan, sekaligus ketidakpercayaan mereka pada pemerintah yang berkuasa. Pada bulan berikutnya, September 2016, demonstrasi ini ditandingi oleh kelompok "kaos merah" yang merupakan pendukung pemerintah. Mereka digerakkan oleh organisasi pro pemerintah, yakni Perkasa dan juga UMNO. Ribuan pendukung kaos merah turun ke jalan-jalan di Kuala Lumpur melakukan long march, untuk menunjukkan aksi dukungan terhadap 
pemerintah Malaysia sekaligus sebagai tanggapan atas unjuk rasa Bersih yang anti-pemerintah. Pada sisi lain aksi ini juga untuk menunjukkan dominasi etnik Melayu dalam politik Malaysia, karena sebagian besar demonstran yang ikut adalah warga etnis Melayu.

Insiden demonstrasi besar berulang lagi pada akhir bulan November 2016, di mana ribuan orang berkaos kuning, kelompok pro demokrasi, Bersih, menggelar aksi di Kuala Lumpur untuk menuntut pengunduran diri PM Najib Razak. Demonstrasi ini diikuti oleh mantan Perdana Menteri Mahathir Mohamad yang menganggap pemerintahan Najib sudah kehilangan legitimasi dan layak diturunkan. Ini merupakan demo kedua yang diaorganisir kelompok Bersih dalam kurun 15 bulan. Namun gerakan mereka, sekali lagi, ditandingi oleh kelompok kaos merah yang pro pemerintah, sehingga nyaris terjadi bentrokan kedua belah pihak.

Salah satu tulang punggung utama dalam gerakan-gerakan protes itu adalah golongan muda terpelajar, generasi muda Malaysia yang sadar akan hak-hak politiknya yang berasal dari berbagai etnik. Namun demikian, menyatunya kelompok-kelompok oposisi dalam jumlah besar, khususnya orang Cina dan India, pada derajat tertentu menimbulkan kekhawatiran pada orang Melayu, dan menempatkannya pada posisi dilematis. Pada kalangan ini,runtuhnya koalisi pemerintahan Barisan Nasional dengan dominasi UMNO bisa jadi akan mengikis pengaruh orang Melayu dalam pemerintahan dan politik. Indikasi agresifitas beberapa kelompok Cina dan India terhadap pemerintah dianggap sebagai suatu serangan eksplisit terhadap dominasi Melayu. Karena itu, sebagian besar golongan Melayu, bersikap lebih berhati-hati dan tetap mendukung pemerintah. Dalam sepuluh tahun terakhir, kekhawatiran ini ditanggapi sebagian golongan Melayu dengan mendirikan organisasi, Pertubuhan Pribumi Perkasa Malaysia (Perkasa).

Perkasa merupakan organisasi NGO berhaluan ultranasionalis yang disponsori sebagian politisi UMNO. Organisasi ini bertujuan 
memperjuangkan dan mempertahankan hak-hak orang Melayu dan pribumi di Malaysia. Perkasa berdiri tahun 2008 dan memiliki cabang-cabang di sebagian besar negara bagian. Kalangan etnik non Melayu menyebut organisasi tersebut sebagai rasis dan sengaja disiapkan pemerintah untuk menghadang gerakan-gerakan oposisi. Dalam berbagai kesempatan Perkasa tampil sebagai kelompok penekan, bertindak mengerahkan massa pengikutnya dalam melawan kelompok-kelompok yang berseberangan dengan pemerintah. Para eksponen Perkasa meyakini bahwa tindakan mereka merupakan bagian dari usaha untuk membela kepentingan orang-orang Melayu, khususnya pemerintah yang didominasi UMNO. Mereka mencurigai agenda politik terselubung kelompokkelompok non Melayu yang berlindung di bawah partai-partai ataupun kelompok-kelompok yang berlabel multi etnis. Belakangan, sebagai kelanjutan respon terhadap kecenderungan-kecenderungan politik, terutama yang berunsurkan perkauman serta agresifitas golongan minoritas, Perkasa dan 22 NGO membentuk aliansi dengan mendirikan organisasi Badan Bertindak Melayu Islam (Bertindak) (www. freemalaysiatoday. com tanggal 16 Juni 2017).

Dalam konteks pembangunan nasional di Malaysia, kemajuankemajuan pembangunan dan dinamika politik telah mereproduksi kelompokkelompok baru, bukan hanya yang berorientasi pada kemajuan tetapi juga pada preservasi kelompok yang merasa belum siap bertransformasi dalam arus besar perubahan yang menempatkan agenda rakyat sebagai tujuan bersama. Meskipun wujud kerjasama lintas etnik di antara kekuatan-kekuatan politik serta masyarakat sipil di Malaysia, namun sejauh ini hanyalah bersifat taktis dan tidak memiliki dimensi yang berjangkauan jauh ke depan. Hal tersebut disebabkan oleh adanya hambatan doktrinal ideologis, adanya prasangka, serta kurangnya rasa kepercayaan di antara masing-masing kelompok. Tidak dapat disangkal lagi bahwa meskipun keadaan ekonomi dan politik negara tersebut cukup baik, 
tetapi di masa-masa mendatang tetap harus berjuang menghadapi situasi sosio-ekonomi yang rapuh.

Usaha-usaha Anwar Ibrahim untuk mengkonsolidasikan kekuatan Barisan Alternatif yang berunsurkan partai-partai lintas etnik sepuluh tahun lalu yang diimpikan akan menjadi saingan bagi Barisan Nasional masih belum cukup kuat menghadapi dominasi Barisan Nasional. Tantangan besar ke depan dalam dimensi politik Malaysia adalah bagaimana menciptakan suasana politik yang lebih terbuka dan akomodatif terhadap kepentingan etnik yang beragam. Dengan kata lain, keberhasilan pembangunan dan pembinaan negara bangsa di masa depan lebih banyak ditentukan pada bagaimana cara menciptakan keseimbangan politik berdasarkan kepentingan ras secara proporsional. Tindakan-tindakan politik yang melangkahi konsensus nasional yang selama ini dijalankan justru akan mengakibatkan keruntuhan sistem itu sendiri serta membuyarkan harapan bagi terwujudnya suatu bangsa yang kuat.

\section{KESIMPULAN}

Malaysia merupakan negara yang bersifat multietnik, di mana faktor etnik menjadi landasan kepentingan politik. Selama ini, usaha-usaha untuk menciptakan integrasi nasional diarahkan pada upaya untuk memperkuat relasi antara kelompok etnik serta menciptakan keseimbangan politik bagi semua kaum. Keberhasilan pembanguan Malaysia tidak terlepas dari komitmen pemerintah yang berkuasa untuk melakukan transformasi dengan merekonstruksi pembangunan ekonomi secara radikal melalui kebijakan afirmasi terhadap golongan pribumi Melayu, merancang sistem pendidikan yang menanamkan kesadaran nasional, serta memperkuat kedudukan bahasa Melayu sebagai bahasa nasional.

Gugatan terhadap pembangunan negara bangsa di Malaysia mengalami ujian berat ketika tahun 1998 negara tersebut didera krisis ekonomi yang berujung pada konflik politik antara Mahathir dan deputinya yakni Anwar Ibrahim. Konflik tersebut 


\section{JURNAL ILMIAH MIMBAR DEMOKRASI}

membawa perpecahan politik di kalangan bangsa Malaysia, khususnya kaum Melayu, di mana banyak di antara mereka memberikan sokongan kuat pada partai-partai oposisi dalam pemilihan umum 1999. Pasca pemerintahan Mahathir Mohamad politik Malaysia mengalami transformasi baru. Di bawah Perdana Menteri Abdullah Ahmad Badawi yang pragmatik usaha-usaha untuk memupuk persatuan nasional khususnya di kalangan golongan Melayu, serta hubungan di antara kaum dilakukan dengan memperkenalkan konsep Islam Hadhari atau Islam moderat yang bertumpu pada pengetahuan dan kemajuan peradaban Islam.

$$
\text { Sementara pada masa }
$$

kepemimpinan Najib Razak, sejak tahun 2009 sampai sekarang, usahausaha untuk mewujudkan masyarakat Malaysia yang padu dilakukan secara lebih progresif lagi dengan mengenalkan konsep One Malaysia, yakni suatu slogan yang secara substantif bertujuan meleburkan perbedaan-perbedaan antar golongan dalam satu visi negara bangsa yang bersatu di bawah dominasi Barisan Nasional. Keberhasilan pembangunan dan pembinaan negara bangsa di masa depan lebih banyak ditentukan pada bagaimnana cara menciptakan keseimbangan politik berdasarkan kepentingan ras secara proporsional berdasarkan konsensus nasional.

\section{DAFTAR PUSTAKA}

Abdullah Ahmad Badawi, Islam Hadhari Approach: Towards A Progressive Islamic Civilisation, Kuala Lumpur: Department of Islamic Development Malaysia Prime Minister's Department, 2007.

Abdul Hadi Awang, Hadharah Islamiyyah Bukan Islam Hadhari, Kuala Lumpur: Nufair Street, 2005.

Abdul Rahman Embong, Negara Bangsa: Proses dan Perbahasan, Bangi: Penerbit Universiti Kebangsaan Malaysia, 2000.

"Demonstrasi di Malaysia Dibubarkan Aparat", www. bbc. com/indonesia/dunia tanggal 28 April 2012, diunduh pada 
tanggal 8 Juni 2017 pukul 13. 59.

Chamil Wariya, Kesinambungan dan Perubahan: Malaysia di Bawah Pentadbiran Abdullah Ahmad Badawi, Kuala Lumpur: Utusan Publications \& Distributors, 2004.

"Coalition of 22 Malay Muslim NGOs Wants Hindraf Banned". www. freemalaysiatoday. com 6 April 2017, diunduh pada tanggal 16 Juni 2017 pukul 10. 46).

Hilley, John, Malaysia: Mahathirism, Hegemony and the New Opposition, London: Zed Books, 2001.

Hussin Mutalib, Islam and Ethnicity in Malay Politics, Oxford: Oxford University Press, 1990.

Jamaie Hj. Hamil, UMNO Dalam Politik dan Perniagaan Melayu, Bangi: Penerbit Universiti Kebangsaan Malaysia, 2004.

"Kenaikan Harga Memicu Unjuk Rasa",Kompas, 2 Januari 2014.

Lee, H. P. , Constitutional Conflicts in Contemporary Malaysia, Oxford: Oxford University Press, 2017.

Means, Gordon P., Malaysian Politics: The Second Generation, Singapore: Oxford University Press, 1990.
Milne, R. S. \& Mauzy, Diane K. Politics and Government in Malaysia, Singapore: Federal Publications, 1978.

Roff, William R. , The Origins of Malay Nationalism, Oxford: Oxford University Press, 1994.

Suhana Saad, "Re-Building the Concept of Nation Building in Malaysia", Asian Social Science, Volume 8, No. 4 p. 24-39, 2012. 